\title{
Magical Girl Martyrs: Puella Magi Madoka Magica and Purity, Beauty, and Passivity
}

\author{
Tate James, Comparative Literature*
}

\begin{abstract}
The Japanese animated television show (or "anime"), Puella Magi Madoka Magica, has garnered significant popularity. Anime fans and critics alike often hail the show as a progressive criticism of the magical girl genre. Indeed, the show gives its female characters complex, nonlinear narratives, breaking down the dichotomy between innocent young girls and evil old women that is prolific within the magical girl genre. While Madoka Magica does make important headway in the realm of dismantling harmful female archetypes, the moral judgments the show assigns to those archetypes, coupled with the regressive ways in which it represents female agency, problematize such a positive reading. In order to address this issue, I will briefly examine the history of magical girl anime, locating Madoka Magica within its generic tradition. I will perform a close reading of the show through a feminist critical perspective in order to assess the way that the elements of the show critics have cited as progressive function within its broader narrative, especially in relation to female purity and agency. I argue that Madoka Magica's revolutionary potential is stifled by the fact that it demonizes impurity at the same time as it portrays impurity as almost inescapable, ultimately suggesting that the only acceptable strategy for girls is to be completely passive in order to remain pure.
\end{abstract}

\section{INTRODUCTION}

Puella Magi Madoka Magica's Mami Tomoe is the perfect magical girl. She is the other girls' ultra-competent, beautiful mentor: she is completely self-sufficient (despite only being about fourteen years old), wears her hair in ribbon-bound ringlet pigtails, is clad in a miniskirt and tights, and defeats her enemies with an easy grace. It is shocking, then, when seconds after she believes she has defeated her most recent enemy, its corpse transforms into a smiling, sharp-toothed monster and swallows her whole.

If one were to ask a Puella Magi Madoka Magica (hereafter Madoka Magica) fan when the series hooked her, she would probably reply that it was during this scene. Until this moment, the show adhered rigorously to the tropes of the magical girl genre: young girls transform into magical versions of themselves in be-ribboned and be-ruffled

\footnotetext{
* Tate is a student at the University of Oregon Robert D. Clark Honors College pursuing a degree in comparative literature, with emphases upon Japanese and creative writing. She is interested in popular culture, gender issues, shoujo anime and manga, and queer studies; she is especially interested in these topics when they happen to intersect. She is also working on her thesis, a coming of age novella that will engage with the literary history of monster women in fantasy and magical realist writing, as well as issues of gender, motherhood, and selfdetermination. Please direct correspondence to: tate.j.james@gmail.com.
} 
costumes and fight nonhuman enemies with sparkly weapons. Introducing death to the narrative in any capacity is, therefore, shocking. Madoka Magica continues to reinforce this twist as the girls die one by one, some of them even committing suicide. While other magical girl shows focus on positive, albeit fantastically unrealistic, female empowerment, Madoka Magica breaks this mold by punishing and disempowering its characters. Critics like Lien Fan Shen, Sarah Cleto, Erin Ball, and others, contend that the show's deconstruction of the long-standing magical girl tradition-dichotomizing innocent young girls against evil old women-coupled with its innovative use of complex, non-linear storytelling, cements the show as a progressive one. The end of the series, however, problematizes such a positive interpretation. In contrast to the general critical consensus, I seek to demonstrate here that Madoka Magica's revolutionary potential is ultimately harnessed for a regressive vision of female purity and passivity. Although the show does indeed interrogate problematic female archetypes, it does so to troubling ends-condemning its characters for the impurities it assigns to them. The end result is the suggestion that girls should be passive in order to remain pure in the face of an overwhelmingly oppressive system, even if it costs them their lives.

I will address these issues by examining the history of the mahou shoujo (magical girl) anime (Japanese animation) genre and the tropes therein. Akiyuki Shinbo's Madoka Magica was released two decades after the magical girl genre was firmly established as a sizeable offshoot of the broader shoujo (girl's) genre of anime and manga (Japanese comics, which are tied closely to anime). Given that, it is important to examine the way the anime uses those tropes in relation to their history. I will also approach the anime from a positive critical perspective (namely, through Cleto, Bahl, and Fan Shen) in order to assess its triumphs. Lastly, I will use a feminist perspective to examine elements that critics have identified as progressive, and assess the way these elements function within Madoka Magica's broader narrative in relation to female agency and purity. For the purposes of this paper, "progressive" refers to positive representation for girls and women that pushes against the traditionally misogynistic, flat, passive depictions that they are often afforded. "Regressive" refers to representations that either do not push against the status quo of female representation, or actively move backward toward more traditional modes. I address the question: To what extent does female action have meaning, and how is purity positioned within the show's moral framework?

\section{MAGICAL GIRLS: BACKGROUND}

Although the magical girl (mahou shoujo) genre did not coalesce until Naoko Takeuchi's Pretty Soldier Sailor Moon (Sailor Moon) was released in 1992, "fierce but beautiful female warriors" have existed in Japanese animation since the 1960 s (Allison 129). This long anime tradition of pretty soldiers like Sailor Moon includes young girl protagonists (often in middle school) who use magical objects to transform into hyperfeminine versions of themselves in colorful be-ribboned and be-ruffled dresses. Magical girl anime relies on multiple female characters; it is rare for magical girls to fight alone. 
Most significantly, works in this genre have historically been created by women and intended for young girls. Sailor Moon's creator, Naoko Takeuchi, for instance, is a woman; similarly, Cardcaptor Sakura was created by CLAMP, an all-female manga and anime team.

Female creative control, however, does not automatically lead to the production of feminist masterpieces. Lien Fan Shen "attempts to complicate the idea that shoujo heroines are de facto female empowerment in magical girl anime," arguing that "while this direction of argument is accurate to a certain extent, it may bypass the complexities of magical girls who function as empowerment and yet are a product for consumption" (187). And indeed-how can magical girls empower women if their ultimate function is to be consumed? Narrative is almost always of secondary importance to magical girl shows, as the genre has often been a commercial vehicle for tie-in toys and merchandise. The genre-defining magical weapons, for example, are easily commoditized for fan consumption (Rusca 1). Moreover, magical girls visually embody this function: they are, without exception, excessively cute. Thus mahou shoujo offers an especially narrow avenue of empowerment. In order to be powerful, the genre suggests, girls must also be adorable or beautiful. This allows them to remain non-threatening and thus palatable to mainstream audiences. The result is a parade of defanged girls who have significant agency but ultimately do not threaten patriarchal norms. This over-performance of physical femininity compensates for the ways in which magical girls aberr from femininity in other ways: they are permitted their accomplishments and triumphs so long as they unerringly appeal to mainstream beauty standards. Significantly, this is one of the few tropes that Madoka Magica does not address. All of the characters in the show are excessively cute, and this cuteness is never drawn attention to or called into question. Rather, it is portrayed as a natural aspect of the mahou shoujo universe-of course girls should be cute, regardless of how else they might transgress gender boundaries.

Magical girl anime further waters its messages down by upholding stereotypes surrounding innocent young girls and evil older women. Kathryn Hemmann cites Kotani Mari's argument that in many Japanese science fiction novels, girls tend to be defined by their sexual availability to men. Young women are portrayed as pure-hearted and sexually inexperienced, while older women are experienced but unavailable-and therefore literally monstrous. Hemmann argues that this trend was carried from science fiction into magical girl anime and manga (57). In Sailor Moon, for example, Sailor Moon is the "pretty soldier in a sailor suit [Japanese school uniform]," and is often referred to as "pure-hearted." She fights mature, scantily clad, busty, anthropomorphic female monsters-and defeats them by "cleansing" or "healing" them. Thus the show literally pits pure young girls and sexualized older women against one another, demonizing the latter group by positioning them as literal monsters and villains. The influence of seminal magical girl works like Sailor Moon can be seen in later shows, such as Cardcaptor Sakura (1998) and Day Break Illusion (2013), in which young girls are also pitted against 
mature, sexualized monster women. The trope is prolific-it is difficult to find a magical girl piece that does not contain a binary between innocent girls and mature women.

The fact remains, however, that magical girl anime is one of few genres that directly caters to women. Many female fans find magical girl anime empowering, citing the girls' purity and cute outfits as encouraging specifically because they are so feminized (Hemmann 15). Lianne Sentar describes her personal experiences with Sailor Moon, writing: "Sailor Moon combined the aspects of power I had always coded as masculine with the power of female desire," arguing that the way powerful female characters move the show's plot while male characters like Tuxedo Mask are relegated to the sidelines is indicative of a "female gaze" (8). ${ }^{1}$ Sentar's outsider status as an American allows her to shed light on the global significance of female agency and perspective in Sailor Moon. Young girls are not forced to look at the world through a man's eyes when watching the series; rather, the magical girl universe shows them powerful, beautiful, and, most importantly, relatable girls triumphing against seemingly impossible odds. When watching most magical girl shows, one cannot shake the feeling that one has entered a world that is first and foremost concerned with women; men are permitted (and even encouraged) to spectate, but they are afforded no more influence than that.

\section{PUELLA MAGI MADOKA MAGICA}

Madoka Magica consciously positions itself within the magical girl tradition. In the show, cute, color-coded Magical Girls (hereafter capitalized to avoid confusion between the show's Magical Girls and magical girls as a broader category) fight against witches, who enshrine themselves in labyrinths-enormous, fantastical spaces that the girls must battle through to reach the witches at the center. When witches are defeated, they leave "grief seeds" behind, which Magical Girls use to purify their own "soul gems." The soul gems literally contain Magical Girls' souls; when the girls despair, their gems are filled with darkness, and they must purify them in order to survive. Occasionally, they must also fight "familiars," beings similar to witches that do not leave grief seeds behind but which will become witches if they take enough lives. The show's protagonist, Madoka Kaname, spends almost the entirety of the show grappling with the decision whether or not to become one of these super heroines as she watches her Magical Girl friends, Homura, Sayaka, Mami, and Kyoko, from the sidelines.

While many other magical girl shows give their heroines unique names (like Sailor Moon's "sailor soldiers"), Madoka Magica simply refers to its protagonists as "Magical Girls." This prevents the viewer from perceiving Madoka Magica as simply an interpretation or expansion of the magical girl genre-one understands that the show is addressing its genre directly. Furthermore, one cannot be immersed in Madoka Magica's world without thinking about the magical girl genre because its name is repeated within the show's diegesis over and over again. Thus the show positions itself as being, if not deconstructive, interrogative; its aberrations from the magical girl genre should be interpreted not as expansions, but as critiques. 
Madoka Magica makes an incisive critique against the flat, shallow depictions of women and girls that are common in the genre. These critiques are located in its depiction of witches, their labyrinths, and their relationship to the Magical Girls. Each witch's labyrinth is unique, and is composed of a series of opaque, but interrelated symbols that the witch uses to protect herself from her enemies. Calling the witches' labyrinths "narrative spaces they control," Cleto and Bahl argue that the labyrinths are more than physical spaces-they are complex, nonlinear narratives. They write that Madoka Magica's "witches can simultaneously reshape their environment and create a powerful statement about identity through personalized performance" (1), and that "the labyrinths are too complex to afford a one-to-one correlation between symbol and interpretation; their objects' richness lies in their ambiguity and their ability to evoke rather than signify absolutely" (7). They specifically reference Sayaka's (or, as a witch, Oktavia's) labyrinth, arguing that because the viewer knows Sayaka's story, the elements of her labyrinth are especially meaningful (even if they are ambiguous). This kind of storytelling is unique within the magical girl genre; magical girls are rarely given the means to express themselves in such three-dimensional and personalized ways.

Madoka Magica also attempts to destabilize the dichotomy between innocent young girls and impure adult women. Fan Shen argues that the show

"defies the binary representation of princesses and witches that takes representation of women for granted, breaking the signifying chain of animation representations of women: princesses versus witches, good versus evil, young versus old, pretty versus ugly, and sweet versus furious" (185).

The show first appears to uphold this traditional dichotomy: the witches are animated in a collage style different from the rest of the series' animation. This emphasizes the supposed difference between witches and magical girls. The late revelation that all witches were once Magical Girls and that all Magical Girls will inevitably become witches is not only shocking, but also effective. The viewer is forced to reconsider her assumption about the witches, an assumption that the show has consciously shaped by delineating so sharply between witches and Magical Girls. The Magical Girl/witch dichotomy is evocative of gendered dichotomies in other works within the genre, like Sailor Moon and Magical Girl Lyrical Nanoha. The viewer is thus encouraged to reflect upon these broader dichotomies. If one does take the time to reflect, it becomes apparent that Madoka Magica's witches were never especially separate from Magical Girls after all: from the beginning, most of the labyrinths have contained a mixture of girlish and macabre imagery. Gertrud, the show's first witch, is so bulbous and globular that Sayaka calls her "disgusting" when she first sees her; however, most of the witch's actual body is made of a rose bush, which is typically a beautiful feminine symbol. The labyrinth itself contains roses with stems that look exactly like barbed wire, further blurring the line between girlish and sinister. At first glance, the roses juxtaposed against the barbed wire and Gertrud's body makes her seem abjectly grotesque, because, according to the binary representations that Fan Shen refers to, innocence and wickedness are diametrically 
opposed to one another. But the revelation that witches and magical girls are inextricably linked-that one girl can be both a magical girl and a witch in her lifetime-complicates Gertrud's supposed abjection.

Moreover, Madoka Magica's magical girls are not especially pure, even before they become witches. They only transform into witches when their soul gems become completely corrupted-and, as Homura says in episode nine, becoming a witch is every magical girl's "inescapable fate." If becoming a witch is inescapable, then all magical girls must be, by merit of their identity, corrupt at some level. The only way to stave off complete corruption is to become selfish and cruel: Homura says that "girls like" Kyoko, the harshest and cruelest girl in the series, "are most suited to be[ing] magical girls" because it takes them longer to succumb to despair. Kyoko repeatedly exhibits cruelty, attacking Sayaka for her perceived weakness, and literally trying to kill her. Because witch's familiars do not drop grief seeds, but turn into dangerous, full-blown witches when they have murdered enough people, Kyoko waits for them to evolve before she defeats them, then uses the grief seeds to stave off her soul gem's corruption. Her purity, then, comes directly at the cost of human lives. Kyoko's callousness is shocking; one does not expect such a blasé approach to death from a middle school-age girl. The impact of Kyoko's personality contributes to the destabilization of the Magical Girl/witch dichotomy by calling traditional magical girl notions of purity into question. If Kyoko can remain "pure" only by permitting atrocities, then what, exactly, does "purity" even mean?

The disparity between Kyoko's personality and the constructed purity of her soul gem defamiliarizes the purity/impurity binary by drawing attention to their construction. Further, the show's approach to purity mirrors Judith Butler's perception of gender as being "in no way a stable identity or locus of agency from which various acts proceed" (Butler 519). Like Butler's conception of gender, purity has absolutely nothing to do with identity at all. Significantly, purity (especially in the context of the magical girl genre) is a particularly gendered construction. If the traits associated with femininity are merely constructed, then what does that mean for femininity as a whole? Moreover, the fact that Magical Girls can technically embody female-coded purity at the same time as they enact taboo and even male-coded traits, calls the construction of gender itself into question. ${ }^{2}$

The show also positions cruelty as a survival strategy, emphasizing the impossibility of living up to the standards of feminine innocence. Against her better judgment, Kyoko eventually comes to care about Sayaka-but because she cares about her so much, she kills herself in the battle against her friend's witch-form, thereby directly connecting her compassion with death. Thus impurity, whether physical or not, is inescapable: either Magical Girls' soul gems are tangibly infected with corruption, or they hurt others, thereby corrupting themselves in a more abstract but nevertheless significant way. Madoka Magica restructures the familiar figure of the magical girl, suggesting that innocence and witch-like wickedness are not so separate after all-which in turn critiques dichotomous readings of feminine identity. 
Although Madoka Magica destabilizes the pure/impure dichotomy, it does absolutely nothing to question the moralism inherent to that dichotomy. In fact, it reinforces it, suggesting that the girls should resist the literally inescapable pull of corruption even if it means they must suffer and die. Kyoko's sacrifice is portrayed as heroic-the fact that she dies because she is caught in the throes of an unjust system takes the backseat to the fact that that willingness, according to the show, is character development. The most resounding endorsement of purity comes at the end of the series when Madoka ascends to godhood and changes the structure of the universe so that there have never been and will never be any witches ever again. In Madoka's new world order, corruption literally leads to death. The show frames this as a happy, if bittersweet, ending. Before she dispels the final witch, Walpurgisnacht, Madoka appears to her glowing-enshrined in pink sparkles, hands open and arms outstretched. The image is reminiscent of Christian depictions of angels and saints, suggesting that the destruction of witches-and all of the impurity associated with them-is so good that it is literally holy. Madoka is depicted similarly in the montage that follows, benevolently greeting Magical Girls that have been consumed with corruption and helping them disappear before they can transform into witches (the show gives no more exposition than that; whether the girls die when they "disappear" is unclear). Thus Madoka Magica condemns girls for their impurity at the same time as it represents that impurity as inescapable: better to die, the show suggests, than to let oneself become corrupted.

Madoka's erasure of past and present witches also has regressive implications for female agency. Nothing the characters have done over the course of the show means anything-before Madoka's godhood, Homura goes back in time again and again to prevent Madoka from becoming a magical girl, but Madoka becomes one anyway in every single timeline. Often, happiness is snatched away the moment it is achieved: Mami dies moments after experiencing the first time she'd "ever felt so happy in a fight;" Sayaka becomes a magical girl in order to give the boy she loves the ability to play music again, but her friend confesses her love to him before she can. When Homura finally does rescue Madoka from dying as a witch, she discovers that Madoka will now "exist only as a concept" and she will never be able to speak to her again. Significantly, each instance of stolen happiness occurs after the culmination of hard work (Homura's time travel, for instance)-the fact, then, that that happiness never lasts longer than a moment or two reinforces the meaninglessness of the girls' actions. Moreover, when Madoka erases the existence of witches, they are replaced by wraiths, and the Magical Girls must continue to fight anyway. Thus even the most meaningful moment of female agency in Madoka Magica-after all, Madoka "unravel[s] the fabric of time itself," which is no small feathas little tangible effect upon her world, serving only to reaffirm passivity. Furthermore, Cleto and Bahl write:

As witches, the girls had power, creativity, individual expression, and embodiment in the midst of their despair, the power to shape the world around them with their assembled story-worlds; with Madoka's new system, however, 
even that ambiguous power and creativity is denied them, and they are literally wiped out of existence. In taking the magical girls' despair upon herself, Madoka has not saved them; she has trapped them further by ensuring their complete erasure the moment hope or magic fails, and sapping all creative embodied power from their grief (10).

The fact that, again, the show frames Madoka's ascension to godhood as a happy ending suggests that passivity is a good thing; witches do not deserve the power of selfexpression through their labyrinths. Furthermore, in the show's final episode, Madoka repeatedly affirms the importance of hope. She tells the other magical girls to "keep believing" in themselves "to the very end," and Mami says that Madoka is "becoming hope itself." Significantly, hope is not an action; it is an emotion, and it is therefore inherently passive. Thus Madoka utilizes her position as a god-which gives her the utmost material and moral authority-to sanctify and encourage passivity. The result is a resounding endorsement of passivity overall: if magical girls are always, without fail, punished for exhibiting any kind of agency, then the best they can hope for is that they will be punished a little less for doing nothing.

\section{CONCLUSION}

Madoka Magica does not shed light on existing magical girl narratives-rather, it has created a new system. Given that magical girl anime has such a strong history of representing powerful, active women, the complete lack of female agency in the show is actually regressive. Moreover, it bears repeating that mahou shoujo's target audience is young girls-the fact, then, that Madoka Magica encourages passivity and affirms suffering as not only an inescapable aspect of life for girls but also a moral imperative, is problematic at best and deeply harmful at worst. Although the show does destabilize the popular narrative dichotomy between innocent young girls and evil old women, it nevertheless condemns the latter category, suggesting that the only acceptable strategy for girls is to sit still, look pretty, and hope for the best.

\section{ACKNOWLEDGMENTS}

I would like to express my gratitude to Professor Alisa Freedman for her endless support, encouragement, and guidance, and for giving me the freedom to pursue this topic. I would also like to thank Anna Kovalchuk for taking the time to help me with this paper; her feedback on my first draft was hugely influential to the shape the final draft took. I am also grateful to librarian Kevin McDowell for generously taking the time to discuss this project with me, and for starting my journey toward many of the resources that were so integral to this paper. Thank you as well to Meaghan Anderson Forbis for her sharp eye and perennially excellent, thorough advice. I am also indebted to the University of Oregon Libraries not only for housing most of the materials I referenced in this project, but also for making the other research projects I have completed over the 
last four years possible. Lastly, thank you to the Oregon Undergraduate Research Journal for the opportunity to publish my work, and for their generous commitment to providing a platform for student research.

\section{REFERENCES}

Allison, Anne. "Fierce Flesh: Sexy Schoolgirls in Action Fantasy." Sailor Moon, Millennial Monsters: Japanese Toys and the Global Imagination, University of California Press, pp. 128-162.

Butler, Judith. "Performative Acts and Gender Constitution: An Essay in Phenomenology and Feminist Theory." Theatre Journal vol. 40, no. 4, 1988, pp. 519531. Accessed 22 Jan. 2016.

Cardcaptor Sakura. CLAMP, 21 Aug. 1991. Crunchyroll.com, 7 Apr. 1998.

Cleto, Sara, and Erin Kathleen Bahl. "Becoming the Labyrinth: Negotiating Magical Space and Identity in Puella Magi Madoka Magica." Humanities vol. 5, no. 2, 2016, pp. 20.

Day Break Illusion. Aniplex, 6 July 2013. Crunchyroll.com, 6 July 2013.

Fan Shen, Lien. "The Dark, Twisted Magical Girls: Shoujo Heroines in Puella Magi Madoka Magica." Heroines of Film and Television: Portrayals in Popular Culture, edited by Norma Jones et al., Rowman \& Littlefield, 2014, pp. 177-188.

Hemmann, Kathryn. "Short Skirts and Superpowers: The Evolution of the Beautiful Fighting Girl." U.S.-Japan Women's Journal, vol. 47 no. 1, 2015, pp. 45-72, doi:10.1353/jwj.2015.0001.

Foucault, Michel. "Part Four: The Deployment of Sexuality." The History of Sexuality, translated by Robert Hurley, Reissue Edition, vol. I, Vintage, 1990, pp. 77-102.

Lorber, Judith. "'Night to His Day': The Social Construction of Gender." Paradoxes of Gender, Yale University Press, 1994, pp. 13-36.

Mulvey, Laura. "Visual Pleasure and Narrative Cinema." Visual and Other Pleasures. Indiana University Press, 1989. 15-27. Print.

Puella Magi Madoka Magica. Directed by Akiyuki Shinbo, Shaft, 2011. Hulu.com.

Sailor Moon. Toei, 1992. Hulu.com.

Sentar, Lianne. "The Western Sailor Moon Generation: North American Women and

Feminine-Friendly Global Manga." Global Manga: Japanese Comics Without Japan, edited by Casey Brienza, Routledge, 2015, pp. 23-44. 


\section{Rusca, Renato Rivera. "Toy Stories: The Role of Robots and Magical Girls in Anime Marketing." Introducing Japanese Popular Culture, edited by Alisa Freedman and Toby Slade, Routledge, 2017.}

\section{NOTES}

\footnotetext{
${ }^{1}$ Here, Sentar probably references Laura Mulvey's theory of the "male gaze," from her seminal essay, "Visual Pleasure and Narrative Cinema." According to Mulvey's theory, most (Western) cinema is produced with the assumption that viewers are heterosexual men; men are thus encouraged to identify with the film's male subject, while women are reduced to passive objects to be conquered, consumed, or destroyed. Although Sentar perhaps oversimplifies the complexities of Mulvey's argument, it is nevertheless relevant that the male gaze does not exist in quite the same way in magical girl anime as it does in Western cinema. In most magical girl works, there is no male subject at all; thus the way that women and girls function within magical girl narratives simply does not follow the same pattern, yet Sentar's sentiment makes it clear that the show progresses with a strong female perspective.

2 The connection between gendered dichotomies and their construction was derived from Judith Lorber's essay, “'Night to His Day': The Social Construction of Gender," and Michel Foucault's History of Sexuality. Although their work cannot be put directly in dialogue with Madoka Magica itself because they specifically focus upon male/female dichotomies (rather than smaller dichotomies within gender categories), they nevertheless provide an integral frame through which to consider the artifice of gendered binary systems.
} 